\title{
Implementasi total quality management (TQM) perspektif teori Edward Deming, Juran, dan Crosby
}

\author{
Husna Nashihin a,1, ${ }^{*}$, Nazid Mafaza ${ }^{\text {b,2 }}$, M. Okky Haryana c,3 \\ a Universitas Wahid Hasyim, Semarang, Indonesia; \\ b Sekolah Menengah Pertama Negeri 5 Ngawen, Gunung Kidul, Yogyakarta, Indonesia; \\ c Sekolah Tinggi Ilmu Tarbiyah Madani Yogyakarta, Yogyakarta, Indonesia; \\ *1 aufahusna.lecture2017@gmail.c om; ${ }^{2}$ fazama17@gmail.com; ${ }^{3}$ okkyokeharya@gmail.com
}

\section{KATAKUNCI}

Implementasi

Total Quality Management

Teori Manajemen
KEYWORDS

Implementation

Total Quality Management Management Theory

\section{ABSTRAK}

Pengkajian Total Quality Management (TQM) dari perspektif Edward Deming, Teori Juran, dan Teori Crosby sangat urgen dilakukan guna menemukan konstruksi teoritis diterapkannya Total Quality Management (TQM) di lembaga pendidikan. Implementasi teori Edward Deming dapat dilakukan dengan langkah sebagai berikut ciptakan tujuan yang mantap demi perbaikan produk dan jasa, hentikan ketergantungan pada inspeksi masal dalam bidang pendidikan, akhiri kebiasaan melakukan hubungan bisnis hanya berdasarkan biay, perbaiki sistem produksi dan jasa secara konstan dan terus meneru, dan lembagakan metode pelatihan yang modern di tempat kerja. Lembagakan Kepemimpinan. Implementasi Teori Juran dalam Total Quality Management (TQM) dilakukan dengan tiga tahapan berikut, yaitu perencanaan kualitas (Quality Planning/QP), pengendalian kualitas (Quality Control/QC), dan perbaikan kualitas (Quality Improvement/QI). Implementasi Teori Crosby dalam Total Quality Management (TQM) dilakukan dengan langkah sebagai berikut; legitimasi Kebijakan, pengembangan konstituen, akumulasi sumber daya, desain Organisasi dan modifikasi, memobilisasi sumber daya dan aksi, dan pemantauan kemajuan dan dampak perubahan kebijakan.

\section{Implementation of total quality management (TQM) Edward Deming, Juran And Crosby's theory perspective}

The study of Total Quality Management (TQM) from the perspective of Edward Deming, Juran's Theory, and Crosby's Theory is very urgently carried out in order to find the theoretical construction of the implementation of Total Quality Management (TQM) in educational institutions. The implementation of Edward Deming's theory can be carried out in the following steps: create a solid goal for the improvement of products and services, stop dependence on mass inspection in the field of education, end the habit of conducting business relations only on a fee basis, improve production and service systems constantly and continuously, and institute modern training methods in the workplace. Institutionalize Leadership. The implementation of Juran's Theory in Total Quality Management (TQM) is carried out in the following three stages, namely quality planning (Quality Planning/QP), quality control (Quality Control/QC), and quality improvement (QI). The implementation of Crosby Theory in Total Quality Management (TQM) is carried out with the following 
steps; Policy legitimacy, constituency development, resource accumulation, Organizational design and modification, mobilizing resources and action, and monitoring the progress and impact of policy changes.

This is an open-access article under the CC-BY-SA license.

\section{Pendahuluan}

Model peningkatan kualitas manajemen yang bisa diselenggarakan oleh semua lembaga pendidikan untuk meningkatkan kualitas SDM. Perhatian ilmu manajemen terhadap peningkatan mutu suatu produk (industri) dalam dua dasawarsa ini meningkat pesat. Perkembangannya dimulai dari dunia industri dan dianggap berhasil meningkatkan efisiensi dan penjualan produk dunia industri itu. Keberhasilan itu merambah ke setiap bagian kegiatan yang menggunakan manajemen untuk meningkatkan kinerja organisasi usaha atau perusahaan. Salah satu bentuk manajemen yang berusaha untuk meningkatkan dan mempertahankan mutu atau kualitas sebuah produk disebut dengan Total Quality Management (TQM) atau Manajemen Mutu Terpadu (MMT).

Dunia pendidikan juga tidak dapat terlepas dari sistem manajemen di atas. Terdapat beberapa kelemahan mendasar dalam penyelenggaraan pendidikan di Indonesia. Kelemahan mendasar itu antara lain yaitu bidang manajemen yang mencakup dimensi proses dan substansi. Pada tataran proses, seperti perencanaan, pelaksanaan, dan evaluasi belum dilakukan dengan prosedur kerja yang ketat . Pada tataran substantif, seperti personalia, keuangan, sarana dan prasarana, instrumen pembelajaran, layanan bantu, layanan perpustakaan, dan sebagainya, tidak hanya substansinya belum komprehensif, melainkan kriteria keberhasilan untuk masingmasingnya belum ditetapkan secara taat asas . Semua unit yang berada dibawah lembaga pendidikan harus secara integratif dan simultan menerapkan satu sistem demi keberlangsungan penjaminan mutu.

Agar mutu tetap terjaga dan agar proses peningkatan mutu tetap terkontrol, maka harus ada standar yang diatur dan disepakati untuk dijadikan indikator evaluasi keberhasilan peningkatan mutu tersebut (adanya benchmarking/titik acuan standar/patokan). Dalam hal ini sebuah sistem manajemen mutu yang tepat perlu dikembangkan. Dalam manajemen mutu, sudah ada tiga sistem yang berkembang, yaitu Pengawasan Mutu (PM), Jaminan Mutu (JM), dan Manajemen Mutu Terpadu (MMT).

Salah satu permasalahan pendidikan di Indonesia adalah rendahnya mutu pendidikan pada setiap jenjang dan satuan pendidikan, khususnya pendidikan dasar dan menengah. Beberapa usaha telah dilakukan untuk meningkatkan mutu pendidikan nasional, antara lain melalui berbagai pelatihan dan peningkatan kompetensi guru, pengadaan buku dan alat pelajaran, perbaikan sarana dan prasarana pendidikan dan peningkatan mutu manajemen sekolah. Namun demikian, berbagai indikator mutu pendidikan belum menunjukkan peningkatan yang berarti.

Dalam manajemen mutu terpadu (MMT/TQM) keberhasilan sekolah diukur dari tingkat kepuasan pelanggan, baik internal maupun eksternal. Sekolah dikatakan berhasil jika mampu memberikan pelayanan sama atau melebihi harapan pelanggan. Solusi yang sekiranya dapat membantu dalam menghadapi keterpurukan dalam dunia pendidikan, salah satunya perlu menerapkan Total Quality Management atau Manajemen Mutu Terpadu secara konsisten. Untuk itulah, makalah yang sederhana ini akan mencoba membahas tentang Total Quality 
Management atau Manajemen Mutu Terpadu dalam konteks pendidikan.

\section{Metode}

Penelitian ini digolongkan ke dalam jenis penelitian studi pustaka atau literatur. Penelitian studi pustaka dilakukan dengan cara mengumpulkan data-data kajian yang relevan dengan penelitian ini. Pengumpulan data dilakukan dengan cara mengumpulkan data-data yang relevan dari buku-buku maupun jurnal dari internet. Setelah data terkumpul, selanjutnya akan dilakukan pengolahan data dengan menelaah dan mengkaji kemudian mendeskripsikan data serta membuat kesimpulan yang sesuai dengan tujuan penelitian.

\section{Hasil dan Pembahasan}

Total Quality Management (TQM) merupakan konsep yang relatif baru dalam dunia manajemen dan kepemimpinan. Ia sebuah proses peningkatan kualitas yang komprehensif dan berkelanjutan untuk mencapai tujuan-tujuan organisasi. Kepuasan pelanggan yang bermuara pada keunggulan produk atau jasa adalah fokus dari proses TQM ini.

Total Quality Management (TQM) dalam bidang pendidikan tujuan akhirnya adalah peningkatan kualitas, daya saing bagi output (lulusan) dengan indikator adanya kompetensi baik intelektual maupun skill serta kompetensi sosial siswa/lulusan yang tinggi. Dalam pencapaian hasil tersebut, implementasi TQM di dalam organisasi pendidikan perlu dilakukan dengan sebenarnya tidak dengan setengah hati.

Penerapan TQM sebagai upaya peningkatan mutu pendidikan tidak dapat berhasil secara instant, artinya perubahan inovatif yang diharapkan tidak dapat terwujud secara langsung, karenanya diperlukan upaya berkesinambungan agar dapat terwujudkan produktifitas yang tinggi. Selain itu diperlukan juga kebersamaan dan kerjasama seluruh komponen penyelenggara suatu lembaga pendidikan, dalam meningkatkan kualitas sumber daya manusianya.

Ada 3 teori yang terkenal mengenai implementasi TQM yaitu teori Edward Deming, Juran, dan Crosby. Berikut uraian mengenai implementasi 3 teori tersebut;

\section{Implementasi Teori Edward Deming dalam Total Quality Management (TQM)}

Edward Deming menyatakan bahwa implementasi konsep mutu dalam sebuah organisasi memerlukan perubahan dalam filosofi yang ada di sekitar manajemen. Deming mengusulkan empat belas butir pemikiran yang dapat dipergunakan untuk meningkatkan mutu dan produktivitas suatu organisasi juga dalam bidang pendidikan. Implementasi teori Edward Deming dapat dilakukan dengan langkah sebagai berikut; Ciptakan tujuan yang mantap demi perbaikan produk dan jasa.

Sekolah memerlukan adanya tujuan akhir yang mampu mengarahkan siswa menghadapi masa depan secara mantap. Jangan membuat siswa sekedar memiliki nilai bagus tetapi juga harus mampu membuat siswa memiliki kemauan belajar seumur hidup. Adopsi Filosofi Baru Siswa berhak mendapatkan pembelajaran yang berkualitas. Dengan kata lain, mereka tidak lagi sebagai siswa yang pasif dan rela diperlakukan seburuk apapun tanpa dapat berkomentar.

Hentikan ketergantungan pada inspeksi masal dalam bidang pendidikan. Evaluasi yang dilakukan jangan hanya pada saat ulangan umum ataupun ujian akhir, tetapi dilakukan setiap saat selama proses belajar mengajar berlangsung. Selain itu, dalam menetapkan standar uji, maka perlu diperhatikan teoriteori kepemimpinan yang berkembang dalam Total Quality Management dan lainnya, seperti teori sifat, teori lingkungan, teori perilaku, teori humanistik, dan teori kontigensi. Sejalan dengan masalah evaluasi, masalah rekrutmen dalam menentukan pimpinan kependidikan, beberapa prosedur "Fit and proper test" bisa dilakukan 
dalam pengambilan keputusan : (a) Melakukan "hearing" didepan tim, yaitu menyampaikan program, visi dan misi apabila terpilih menjadi pimpinan nantinya. (b) Menjawab pertanyaan lisan dan tertulis yang telah didesain sedemikian rupa. Adapun pertanyaan yang diajukan dapat menyangkut integritas, moralitas, profesionalisme, intelektualitas, keahlian. (c) Keharusan mengumumkan harta kekayaan dari para calon Kepala Sekolah sebelum yang bersangkutan menduduki jabatan yang dipercayakan kepadanya. Kebohongan atas kekayaan ini dapat mengakibatkan pemecatan (impeachmant). (d) Harus memahami sistem manajemen yang efektif dan efisien terhadap lembaga yang akan dipimpinnya. Termasuk dalam rekruitment karyawan, kesejahteraan, peningkatan kualitas hasil dan kinerja. (e) Mengemukakan masalah pribadi, seperti apakah calon itu pernah bercerai. Masalah anak bagaimana. Mengapa sampai terjadi perceraian. Kemudian menyangkut masalah kebebasan dari tekanan, intimidasi, teror atau ancaman. (f) Tim seleksi melakukan investigasi dan melacak semua kebenaran informasi yang disampaikan lisan maupun tertulis. Apabila caloncalon tersebut tidak dapat memberikan jawaban secara memuaskan, atau setelah melakukan investigasi ternyata terdapat kebohongan-kebohongan, tentu saja yang bersangkutan tidak dapat terpilih sebagai pimpinan. Akhiri kebiasaan melakukan hubungan bisnis hanya berdasarkan biaya.

Dalam bidang pendidikan pernyataan di atas terutama dikaitkan dengan biaya pendidikan yang ada hubungannya dengan perbandingan junlah guru dan murid pada satu ruangan/kelas. Kelas besar memang akan membuat sekolah tersebut melakukan penghematan biaya, tetapi mutu yang dihasilkan tidak terjamin dan bukan tidak mungkin terjadi peningkatan biaya di bagian lain pada sistem tersebut. Perbaiki sistem produksi dan jasa secara konstan dan terus menerus.

Dalam bidang pendidikan seorang guru harus berpikir secara strategik agar siswa dapat menjalani proses belajar mengajar secara baik, sehingga memperoleh nilai yang baik pula. Guru jangan hanya berpikir bagaimana siswa mendapatkan nilai yang baik. Lembagakan metode pelatihan yang modern di tempat kerja. Hal ini perlu dilakukan agar terdapat kesamaan dasar pengetahuan bagi semua anggota staf dalam suatu lembaga pendidikan. Setelah itu barulah guru dan administrator mengembangkan keahlian sesuai yang diperlukan bagi peningkatan profesionalitas.

Lembagakan Kepemimpinan. Kepemimpinan (leadership) berbeda dengan pemimpin (leader). Kepemimpinan adalah kemampuan untuk mempengaruhi tingkah laku orang atau kelompok dengan maksud mencapai suatu tujuan yang dinginkan bersama. Sedangkan pemimpin adalah seseorang atau sekelompok orang seperti kepala, komandan, ketua dan sebagainya. Dari beberapa definisi dapat disimpulkan bahwa kepemimpinan itu adalah suatu proses mempengaruhi kegiatan seseorang atau kelompok dalam situasi tertentu untuk mencapai tujuan bersama. Artinya terjadi proses interaksi antara pemimpin, yang dipimpin, dan situasi.

Dengan demikian, kepemimpinan itu seyogianya melekat pada diri pemimpin dalam wujud kepribadian (personality), kemampuan (ability), dan kesanggupan (capability), guna mewujudkan kepemimpinan bermutu atau Total Quality Management (TQM). Dikatakan bahwa, pemimpin yang efektif menurut konsep TQM adalah pemimpin yang sensitif atau peka terhadap adanya perubahan dan pemimpin yang melakukan pekerjaannya secara terfokus. Dalam konsep TQM, memimpin berarti menentukan hal-hal yang tepat untuk dikerjakan, menciptakan dinamika organisasi yang dikehendaki agar semua orang memberikan komitmen, bekerja dengan semangat dan antusias untuk mewujudkan hal-hal yang telah ditetapkan. Memimpin berarti juga dapat mengkomunikasikan visi dan prinsip organisasi kepada bawahan. Kegiatan memimpin termasuk kegiatan menciptakan budaya atau kultur positif dan iklim yang harmonis dalam lingkungan lembaga atau organisasi, serta menciptakan tanggungjawab dan pemberian wewenang dalam pencapaian tujuan bersama. Oleh karena itu dapat dikatakan bahwa, terdapat hubungan positif antara tanggungjawab, 
wewenang dan kemampuan pemimpin dengan derajat atau tingkat pemberdayaan karyawan dalam suatu lembaga.

Secara umum, pada dasarnya terdapat delapan kunci tugas pimpinan untuk melaksanakan komitmen perbaikan kualitas terus menerus, yaitu menetapkan suatu dewan kualitas, menetapkan kebijaksanaan kualitas, menetapkan dan menyebarluaskan sasaran kualitas, memberikan dan menyiapkan sumber-sumber daya, memberikan dan menyiapkan pendidikan dan pelatihan yang berorientasi pada pemecahan masalah kualitas, menetapkan tim perbaikan kualitas yang bertanggungjawab pada manajemen puncak untuk menyelesaikan masalah-masalah kualitas kronis, merangsang perbaikan kualitas terus menerus, dan memberikan pengakuan dan penghargaan atas prestasi dalam perbaikan kualitas terus-menerus.

\section{Implementasi Teori Juran dalam Total Quality Management (TQM)}

Konsep Trilogi dari Joseph Moses Juran dapat diimplementasikan di sekolah untuk mempertahankan dan meningkatkan mutu. Tujuan penelitian ini adalah untuk mengetahui mutu pendidikan di sekolah, berdasarkan hasil akreditasi menurut Standar Nasional Pendidikan (SNP). Selain itu, penelitian ini juga dilakukan untuk mengetahui implementasi konsep The Juran Trilogy di sekolah dan beberapa hambatan yang dihadapi. Metode penelitan ini menggunakan pendekatan kualitatif. Hasil penelitian menunjukkan bahwa mutu sekolah berdasarkan nilai akreditasi, secara umum sangat memuaskan. Akan tetapi perlu ada upaya untuk mempertahankan dan meningkatkan mutu sekolah agar menjadi lebih baik lagi.

Juran lahir di Rumania pada tahun 1900. Setelah lulus dari The University of Minnesota pada tahun 1924, Juran bergabung dalam departemen inspeksi di Bell Telephone's Hawthome Works. Juran sangat berkontribusi dalam perkembangan revolusi mutu. Pemikirannya mengenai manajemen mutu banyak dikembangkan sejak dirinya pindah ke Jepang pada tahun 1954. Juran membantu Jepang dalam merekonstruksi sistem perindustrian di sana agar mampu bersaing dengan pasar dunia dengan konsep mutu yang ditetapkannya.

Menurut Juran, mutu merupakan pekerjaan yang berkaitan dengan manajemen. Menurut Juran, 85\% permasalahan tentang rendahnya kualitas atau mutu sebuah organisasi disebabkan karena manajemen strategi yang buruk. Maka Juran kemudian mengembangkan pikarannya ini dengan sebuah gagasan yang dinamai Manajemen Mutu Strategi (Strategic Quality Management/SQM). Juran menjelaskan bahwa SQM ada tiga golongan dalam staf yang berkontribusi terhadap peningkatan mutu yakni manejer senior yang memiliki fungsi strategis tentang organisasi, manejer menengah yang memiliki fungsi operasional tentang organisasi dan para karyawan yang bertanggungjawab terhadap kontrol mutu.

Juran kemudian mengemukakan tiga elemen pokok dalam proses manajerial suatu organisasi yang dikenal dengan The Juran Trilogy, yakni perencanaan kualitas, pengendalian kualitas dan perbaikan kualitas. Elemen-elemen ini sebenarnya diadopsi oleh Juran dari tiga landasan proses menejerial yang biasa digunakan untuk mengatur keuangan di suatu perusahaan.

Adapun Trilogi Juran tersebut dapat dijelaskan sebagai berikut:

a. Perencanaan Kualitas (Quality Planning/QP).

QP merupakan suatu proses manajemen untuk mengidentifikasi pelanggan, persyaratan/kebutuhan, produk dan jasa yang sesuai dengan karakteristik pelanggan. Proses ini juga akan menghantarkan produk dan jasa dengan perlengkapan yang benar, kemudian mentransfer pengetahuan ini kepada anggota perusahaan sehingga semua pelanggan mendapat kepuasan.

b. Pengendalian Kualitas (Quality Control/QC).

QC merupakan suatu proses pemeriksaan dan evaluasi yang dilakukan secara sungguhsungguh terhadap sebuah produk dan dibandingkan dengan persyaratan utama yang 
diinginkan oleh para pelanggan. Masalah yang terdeteksi akan dikoreksi demi peningkatan kualitas yang lebih baik lagi.

c. Perbaikan Kualitas (Quality Improvement/QI).

QI merupakan suatu proses untuk mempertahankan mekanisme yang sudah baik, agar kualitas dapat dicapai secara terus menerus. Hal tersebut dapat dilakukan dengan cara memperhatikan alokasi sumber daya, menugaskan personil untuk melaksanakan proyek mutu, memberikan pelatihan bagi para karyawan dan menetapkan strategi yang permanen untuk mempertahankan kualitas yang telah dicapai sebelumnya dan mengejar kualitas yang belum sempurna.

Untuk memperbaiki kualitas sebuah organisasi, Juran memberikan beberapa langkah yang harus dilakukan, yakni membentuk kesadaran akan pentingnya perbaikan kualitas dan peluang-peluang untuk melakukan perbaikan, menetapkan tujuan perbaikan, membuat pengorganisasian anggota, mengadakan pelatihan, mengimplementasikan perencanaan program untuk memecahkan masalah, melaporkan perkembangan, memberikan penghargaan, menginformasikan hasil yang telah dicapai, menyimpan dan mempertahanakan hasil yang dicapai, dan melakukan perbaikan dalam sistem reguler perusahaan.

Berdasarkan teori Juran di atas dikemukakan bahwa untuk mempertahankan dan meningkatkan mutu sebuah lembaga pendidikan dibutuhkan manajemen strategi yang baik. Manajemen strategi yang baik ini tidak hanya dibutuhkan oleh sebuah lembaga pendidikan yang memiliki kualitas rendah untuk meningkatkan kualitasnya, tetapi juga dibutuhkan oleh lembaga yang sudah mapan untuk bisa mempertahankan kualitasnya, bahkan untuk lebih menyempurnakan beberapa hal yang menjadi kekurangannya. Oleh karena itu sangat dibutuhkan seorang manejer yang baik dalam mengatur rencana-rencana strategis dan juga bisa menjalankan fungsi kontrol (monitoring) dengan baik.

\section{Implementasi Teori Crosby dalam Total Quality Management (TQM)}

Implementasi teori Crosby dalam reformasi implementasi kebijakan pendidikan dibutuhkan 6 tahapan yakni: Legitimasi Kebijakan.

Dalam implementasi kebijakan, pembuat keputusan kunci harus melihat kebijakan yang diusulkan sebagai legitimasi. Legitimasi kebijakan bisa didapatkan melalui beberapa individu, kelompok, atau organisasi yang menginginkan adanya reformasi kebijakan. Langkah ini dapat melibatkan beberapa individu atau kelompok dengan kredibilitas, sumber daya politik, dan kesediaan mengambil risiko modal politik untuk mendukung kebijakan. Perubahan kebijakan dapat muncul dari berbagai sumber dan harus diakui bahwa kebijakan yang dibuat sebagai kebijakan yang sah dan layak untuk mengawali proses implementasi, sehingga dapat mewujudkan sebuah perubahan dalam pembangunan.

a. Pengembangan Konstituen.

Rendahnya dukungan konstituen dalam implementasi kebijakan menjadi salah satu penghambat reformasi kebijakan publik, oleh karena itu dalam rangka mendapatkan dukungan dibutuhkan adanya pemahaman tentang pentingnya reformasi kepada konstituen. Konstituen dalam hal ini adalah mereka yang akan mendapatkan keuntungan dengan perubahan dalam beberapa cara. Konstituen dalam hal ini bisa menjadi konsumen dari layanan yang disediakan, penyedia input, atau pejabat dalam lembaga pelaksana dan konstituen juga bisa menjadi kelompok dengan yang memberikan pengaruh ke arah perubahan, atau yang dapat membawa semacam sumber daya untuk mendukung perubahan. Pengembangan konstituen yang kuat mengharuskan manajer reformasi kebijakan dalam menggunakan bahasa harus mudah dimengerti dan menarik bagi pendukung potensial, mereka juga perlu untuk membantu kelompok pendukung untuk mengenali dan mengartikulasikan kepentingan mereka sedemikian rupa sehingga mendukung dan memperkuat inisiatif reformasi. Pembangunan dukungan juga berarti menunjukkan orang- 
orang dengan minat yang positif dalam kebijakan, mengubah cara untuk bertindak, bagaimana menjadi berguna, informasi, dan dukungannya harus ditentukan.

b. Akumulasi Sumber Daya.

Dalam mengimplementasikan ke-bijakan baru, sumber daya manusia, teknik, bahanbahan, dan sumber daya keuangan harus dialokasikan dan dipersiapkan terlebih dahulu. Sementara sumber daya eksternal dapat menutupi sebagian dari apa yang akan dibutuhkan, hal ini dapat dilakukan dengan upaya mengumpulkan sumber daya yang cukup. Kegagalan implementasi kebijakan selama ini salah satunya disebabkan karena ketidakmampuan pemerintah untuk mendistribusikan sumber daya dengan prioritas sehingga menyebabkan program atau proyek tidak dapat dilaksanakan dengan baik. Oleh karena itu maka tugas utama pemerintah harus mampu mengakumulasikan semua sumber daya.

c. Desain Organisasi dan Modifikasi.

Pengenalan tugas baru dan tujuan yang menyertai reformasi kebijakan kemungkinan akan menyebabkan modifikasi dalam organisasi pelaksana. Namun, desain organisasi dan/atau modifikasi menimbulkan beberapa masalah. Pertama, karena adanya prosedur yang mengakar dan rutinitas, dan aliansi dengan konstituen dan kepentingan yang ada, sering ada resistensi untuk membuat perubahan baik mandat atau struktur organisasi yang didirikan. Staf tidak dapat berkomitmen untuk menjalankan kebijakan baru atau mungkin menentangnya. Kedua, tugas yang bersifat substansial berbeda dari yang ada saat ini, dan organisasi tidak memiliki kapasitas untuk menjalankannya. Adanya kesulitan dalam membangun rutinitas baru atau tugastugas dalam organisasi, mungkin lebih mudah dan lebih layak secara politis untuk menciptakan struktur baru dari pada merombak yang lama. Staf dalam organisasi yang ada memahami penganggaran, pengadaan, keuangan, dan sistem personil pemerintah dan kemungkinan besar memiliki jaringan politik mereka sendiri. Kondisi ini dapat membantu untuk melakukan sebuah reformasi jika mereka dapat mendukung sebuah perubahan, tetapi mereka merupakan hambatan jika mereka menentang perubahan. Menciptakan organisasi baru memiliki manfaat, di antaranya organisasi menjadi bersih dan mendapatkan dukungan dari banyak pihak, namun untuk mewujudkan semua itu membutuhkan waktu yang lama.

d. Memobilisasi Sumber daya dan Aksi.

Jika perubahan kebijakan adalah untuk mencapai hasil, maka sumber daya dan tindakan harus dimobilisasi ke arah yang tepat. Sebelum sumber daya dan mobilisasi tindakan dimulai, perubahan kebijakan cenderung sebagian besar hanya sebatas tulisan. Sehingga adanya reformasi kebijakan kemungkinan akan menghadapi perlawanan keras dan menghasilkan konflik. Mobilisasi sumber daya memerlukan perencanaan dan pelaksanaan yang baik. Hal ini termasuk penyusunan rencana aksi nyata, klarifikasi target kinerja dan standar, dan kemudian pelaksanaan kegiatan tersebut.

Dalam mewujudkan perubahan dan kemajuan ke depan perlu memperhatikan insentif bagi pelaku kebijakan untuk mengadopsi model baru dan praktek yang dibutuhkan oleh perubahan kebijakan. Tidak adanya insentif yang memadai maka mobilisasi sumber daya akan terganggu. Hal ini dikarenakan jika mereka yang mampu mengendalikan sumber daya dalam organisasi pelaksana tidak merasakan manfaat yang memadai untuk mengubah perilaku mereka, maka kebijakan tersebut tidak akan bisa diterapkan.

Pemantauan Kemajuan dan Dampak Perubahan Kebijakan.

Perubahan kebijakan yang berasil, maka dampaknya akan dibuktikan dalam beberapa cara atau yang lain seperti perilaku berubah, keuntungan yang lebih besar atau lebih baik kepada konsumen atau klien, dan produksi yang lebih efektif atau efisien dalam penggunaan sumber daya, Namun, tidak semua strategi kebijakan perubahan mewujudkan hasil yang positif, manfaat atau niat yang baik. Beberapa kebijakan publik yang diimplementasikan menghasilkan hasil yang tidak diinginkan dan tak terduga dan/atau dampak negatif. Kondisi tersebut terjadi dikarenakan reformasi kebijakan yang bersifat jangka panjang dan manfaat dan dampak tidak muncul secara bersamaan dan tiba-tiba. Oleh karena itu maka pemantauan 
kemajuan dalam bentuk indikator proses sangat penting.

Beberapa indikator proses yang berhubungan dengan pemantauan seperangkat tugas pelaksanaan, selain itu adanya pelacakan indikator ini akan memfasilitasi pembelajaran dan koreksi kesalahan, yang dapat membantu menghindari dampak negatif kebijakan. Pemantauan ini juga penting untuk tujuan akuntabilitas, untuk memastikan bahwa kebijakan yang dijalankan oleh manajer dan lembaga pelaksana memenuhi kewajiban yang telah ditentukan, Pemantauan dapat dilakukan oleh berbagai aktor, tidak hanya pelaksana sendiri. Kemungkinan termasuk penerima manfaat kebijakan di tingkat masyarakat, organisasi masyarakat sipil (NGO, misalnya, LSM pengawas), kampus, bahkan badan internasional.

Pemantauan perubahan kebijakan membutuhkan mekanisme yang baik untuk tinjauan periodik dan evaluasi kebijakan serta untuk melacak di beberapa instansi selama beberapa tahun. Interaksi perubahan kebijakan antar instansi tidak selalu jelas. Hal ini dikarenakan implementasi kebijakan melibatkan beberapa lembaga, sehingga siapa yang memantau dan melaporkan gambaran yang komprehensif Tantang dampak kebijakan keseluruhan kadangkadang bisa menjadi masalah, oleh karena itu di sisi teknis penting untuk melacak efek kumulatif dan interaktif dari semua aktor pelaksana dalam rangka mengetahui output dan perubahan dari adanya kebijakan. Namun, hal ini dapat memerlukan investasi besar dalam monitoring dan evaluasi dan risiko menciptakan sistem yang memberatkan serta mengalihkan perhatian dari pelaksanaannya.

Di sisi birokrasi, pemantauan dan evaluasi laporan dan hasilnya dapat digunakan untuk memberikan reward and punishment bagi pelaksana kebijakan, sehingga kadang dapat memunculkan ketegangan dan konflik. Sedangkan dalam konteks pemantauan independen, pemantauan dapat dilakukan oleh lembaga pengawasan publik dan kelompok masyarakat sipil memainkan peran kunci dalam memastikan akuntabilitas dan responsivitas kebijakan untuk kebutuhan konstituen dan keinginan.

\section{Simpulan}

Implementasi Total Quality Management (TQM) dalam pendidikan sudah banyak menghasilkan kualitas pendidikan yang terjamin. Namun demikian, secara teoritis, belum banyak disajikan teori utama yang menjadi tonggak dirumuskannya Total Quality Management (TQM) dalam pendidikan. Paling tidak, terdapat tiga teori yang melatarbelakangi munculnya Total Quality Management (TQM) dalam pendidikan, yaitu teori Edward Deming, Teori Juran, dan Teori Crosby.

Implementasi teori Edward Deming dapat dilakukan dengan langkah sebagai berikut ciptakan tujuan yang mantap demi perbaikan produk dan jasa, hentikan ketergantungan pada inspeksi masal dalam bidang pendidikan, akhiri kebiasaan melakukan hubungan bisnis hanya berdasarkan biay, perbaiki sistem produksi dan jasa secara konstan dan terus meneru, dan lembagakan metode pelatihan yang modern di tempat kerja.Lembagakan Kepemimpinan.

Selanjutnya, implementasi Teori Juran dalam Total Quality Management (TQM)dilakukan dengan tiga tahapan berikut, yaitu perencanaan kualitas (Quality Planning/QP), pengendalian kualitas (Quality Control/QC), dan perbaikan kualitas (Quality Improvement/QI). Adapun implementasi Teori Crosby dalam Total Quality Management (TQM) dilakukan dengan langkah sebagai berikut; legitimasi Kebijakan, pengembangan konstituen, akumulasi sumber daya, desain Organisasi dan modifikasi, memobilisasi sumber daya dan aksi, dan pemantauan kemajuan dan dampak perubahan kebijakan. 


\section{Daftar Pustaka}

Asmuni, “Konsep Mutu dan Total Quality Management dalam Dunia Pendidikan," Ta'dib XVIII no.1 (Juni, 2013).

Darmadji, "Implementasi Total Quality Management sebagai Upaya Peningkatan Mutu Pendidikan di MAN Model Yogyakarta," El-Tarbawy Jurnal Pendidikan Islam 1 No. 2 November, 2008.

Edward Sallis, Total Quality Mangement in Education. (Yogyakarta: IRCiSoD, 2015).

Marno dan Triyo Supriyatno, Manajemen dan Kepemimpinan Islam (Bandung: Refika Aditama, 2008).

Muchlas Samani, dkk., Manajemen Sekolah (Yogyakarta: Adicita Karya Nusa, 2009).

Koentjaraningrat, Metode Penelitian, (Jakarta : Gramedia, 1983).

Parasuraman A, Leonard Berry, dan Valarie A. Zeithaml, "The Nature and

Determinant of Custumer Expectations of Service," Journal of the Academy of Marketing Science 1 no. 21 (April, 1993).

Sarwadi. 2020. Manajemen Soft Skil Enterpreneurship Santri. Semarang: CV. Pilar Nusantara.

Sugiyono, 2015. Cara Mudah Menyusun Skripsi, Tesis dan Disertasi, (Bandung : Alfabeta).

Suharsimi Arikunto, Prosedur Penelitian, (Jakarta: Rineka Cipta, 2006).

Tenner dan Detoro, Total Quality Management Three Steps to Continous Improvement, (New York: Addison Weley Publishing Company, 1992).

Triana Hermawati, Problematika Manajemen Pendidikan Islam (Telaah Input, Proses, dan Output Dalam Pendidikan Islam). Jurnal Pendidikan Islam At Turots, Vol. 2, No. 2, 2020.

Uhar Suharsaputra, Manajemen Pendidikan Perguruan Tinggi (Bandung: Refika Aditama, 2015). Zeithaml dan Bitner, Service Marketing (New Jersey: Graw Hill, 2000). 